\title{
Meiosis in two human reciprocal translocations
}

\author{
CARLOS SAN ROMÁN, MARÍA TERESA SORDO, AND JOSÉ MIGUEL \\ GAR CIA-SAGREDO
}

From the Departamento de Genética Humana, Fundación Jiménez Díaz, Madrid, Spain

SUMMARY Analysis of meiotic chromosomes from two human male translocation heterozygotes isं reported. One had total sterility after maturation arrest and chain configurations at meiosis, and the second had abnormal children who were presumed to be genetically unbalanced.

The meiotic behaviour of human reciprocal translocations has recently been reviewed by Chandley et al. (1976), who found among their cases a male heterozygous for a balanced reciprocal 9;22 translocation (Chandley et al., 1972), who was studied for infertility after 14 years of childless marriage. This man showed maturation arrest and chain configurations at meiosis, the first report of such an association in man, though such cases of male sterility had been reported by Lyon and Meredith (1966) and Cacheiro et al. (1974) in mice carrying reciprocal autosomal translocations.

This paper presents the meiotic findings of two human reciprocal translocations. One of them is the second known case in man, showing chain configurations at meiosis and associated total male sterility.

\section{Material and methods}

The two cases came from the Infertility Clinic of the Fundación Jiménez Díaz. They were studied after all other urological causes of infertility had been ruled out.

After preparing cultures of peripheral blood lymphocytes (Arakaki and Sparkes, 1963), the chromosomes were analysed by G-banding (Seabright, 1971) and Q-banding (Caspersson et al., 1970). Testicular biopsies were removed under local anaesthesia and meiotic preparations were made by a modified version of the technique of Evans $e t$ al. (1964). The preparations were stained by Giemsa and the C-banding method of Chandley and Fletcher (1973).

Received for publication 3 July 1978

\section{Results}

CASE 1. 46,XY,t(9;11) (q34;q13)

This case (FJD Registry No. 2522/74), aged 33, was childless after 6 years of investigations for infertility In the lymphocyte cultures, a clear translocation be tween two C-group chromosomes was found. With $\mathrm{G}$ อ and Q-banding, a reciprocal translocation between the long arms of chromosomes 9 and 11, 46,XY,t(9;11. (q34;q13) was found. The skin biopsy showed the same abnormality. A family study revealed normap karyotypes in three brothers of the proband. The $\vec{E}$ father was dead and the mother could not be studied? It seems that the translocation was de novo since the other sibs studied presented no abnormalities.

The spermiogram showed severe oligospermi $(1300 / \mathrm{ml})$ with a high percentage of abnorma $\$$ forms and practically non-existent motility. (Un? fortunately the spermiogram did not give figures. Histological analysis revealed hypospermatogenesi with remarkable absence of mature forms (Fig. 1) At meiosis all the stages of the cycle were founds The Table shows the marked reduction in the number of cells in the second meiotic metaphase. The analysis. correlated well with the findings of the spermiograng and the testicular biopsy. An analysis of cells in diakinesis gave a mean chiasma frequency of $48 . \mathbb{R}^{\circ}$ per cell. All the quadrivalents found (Table) hadv the form of an open chain resulting from probable failure of chiasma formation in one arm of the transo location cross at meiotic prophase (Fig. 2).

CASE 2. 46,XY,t(2;11) (p21;q25)

This case (FJD Registry No. 3152/75), aged $40 ?$ presented at our Genetic Counselling Section becaus over the past two years his wife had had twe 


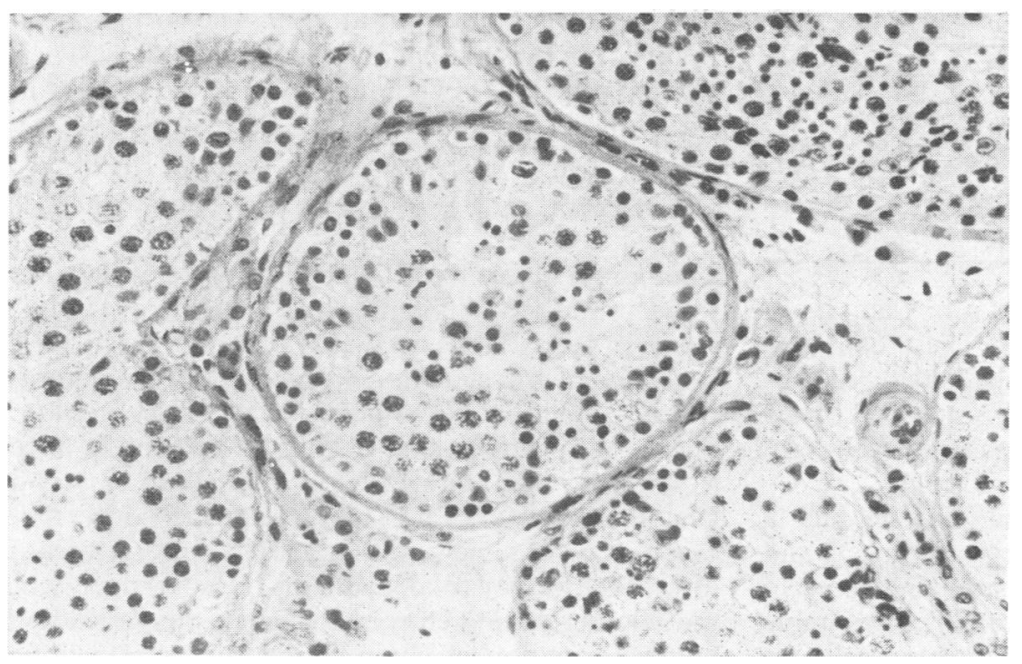

Fig. 1 Case 1. Histology of testicular tissue.

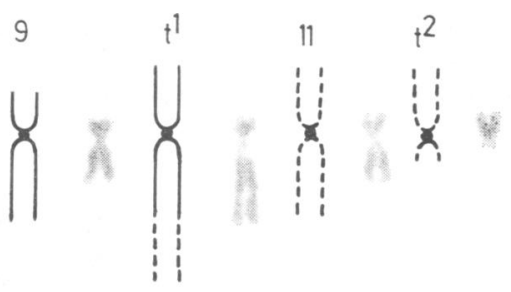

The somatic chromosomes

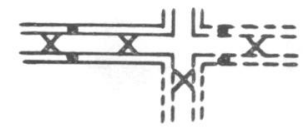

4 chiasmata

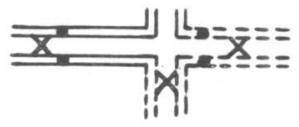

3 chiasmata

Pachytene cross configuration with probable chiasma positions

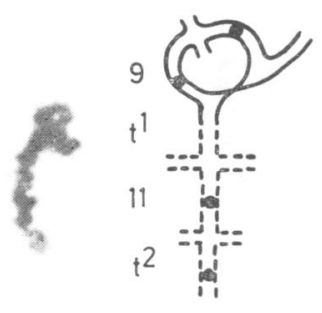

Chain IV at diakinesis

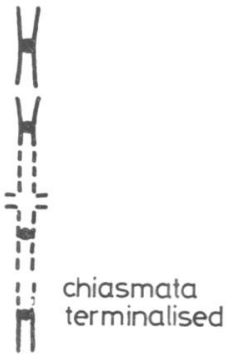

Fig. 2 Case 1. Configuration of somatic chromosomes: probable chiasma position: chain $I V$ at diakinesis. 
Table Distribution of analysed cells

\begin{tabular}{|c|c|c|c|c|c|}
\hline Case & Karyotype & $\begin{array}{l}\text { Spermato- } \\
\text { gonial } \\
\text { metaphase }\end{array}$ & $\begin{array}{l}\text { First } \\
\text { meiotic } \\
\text { metaphase }\end{array}$ & $\begin{array}{l}\text { Second } \\
\text { meiotic } \\
\text { metaphase }\end{array}$ & Total \\
\hline 1 & $\begin{array}{l}46, X Y, t(9 ; 11) \\
(q 34 ; q 13) \\
46, X Y,(2 ; 11)\end{array}$ & $\begin{array}{l}5 \\
(6 \cdot 6 \%) \\
8\end{array}$ & $\begin{array}{l}68 \\
(86 \cdot 0 \%) \\
64\end{array}$ & $\begin{array}{l}6 \\
(7 \cdot 4 \%) \\
60\end{array}$ & $\begin{array}{r}79 \\
132\end{array}$ \\
\hline 2 & (p21;q25) & $(6.0 \%)$ & $(48.4 \%)$ & $(45.6 \%)$ & \\
\hline
\end{tabular}

pregnancies resulting in the birth of a boy and a girl with similar severe malformations. These consisted of polydactyly, hand contracture, cleft palate, cardiopathy, and unspecified renal malformations. They died 19 and 32 days after birth, respectively. An 8-year-old son was phenotypically normal.

The cytogenetic studies showed that he had a balanced translocation between chromosomes 2 and $11,46, \mathrm{XY}, \mathrm{t}(2 ; 11)$ (p21;q25). The surviving son had a normal male karyotype. We were unable to examine any other member of the family. Unfortunately, no spermiogram or testicular histological analysis were obtained. The meiotic studies showed all the stages of spermatogenesis. The Table shows the percentage of cells in each phase. The mean chiasma count for diakinesis was rather low at $35 \cdot 0$. The normal mean number of chiasmata per cell is $50 \cdot 61 \pm 3 \cdot 87$ (Paris Conference, 1971). The quadrivalent was always the form of a ring (Fig. 3).

\section{Discussion}

Though we report these two cases together, there âfe some important differences between them. Case- 1 seems to be, as far as we know, only the second case of a human translocation to show chain configureations at meiosis and associated total male sterilify. Such translocations have also been reported in mige (Lyon and Meredith, 1966). These authors, and Chandley et al. $(1972,1976)$, who described the first case in humans, believe that the maturation breaik down followed by total sterility is the consequence $8 \mathrm{f}$ the telomeric and centromeric break points leading to the formation of chain quadrivalents at meiotif metaphase, conditions which are present in our case. The few cells which are able to complete spermategenesis and produce gametes are clearly not presei in sufficient numbers to achieve fertilisation.

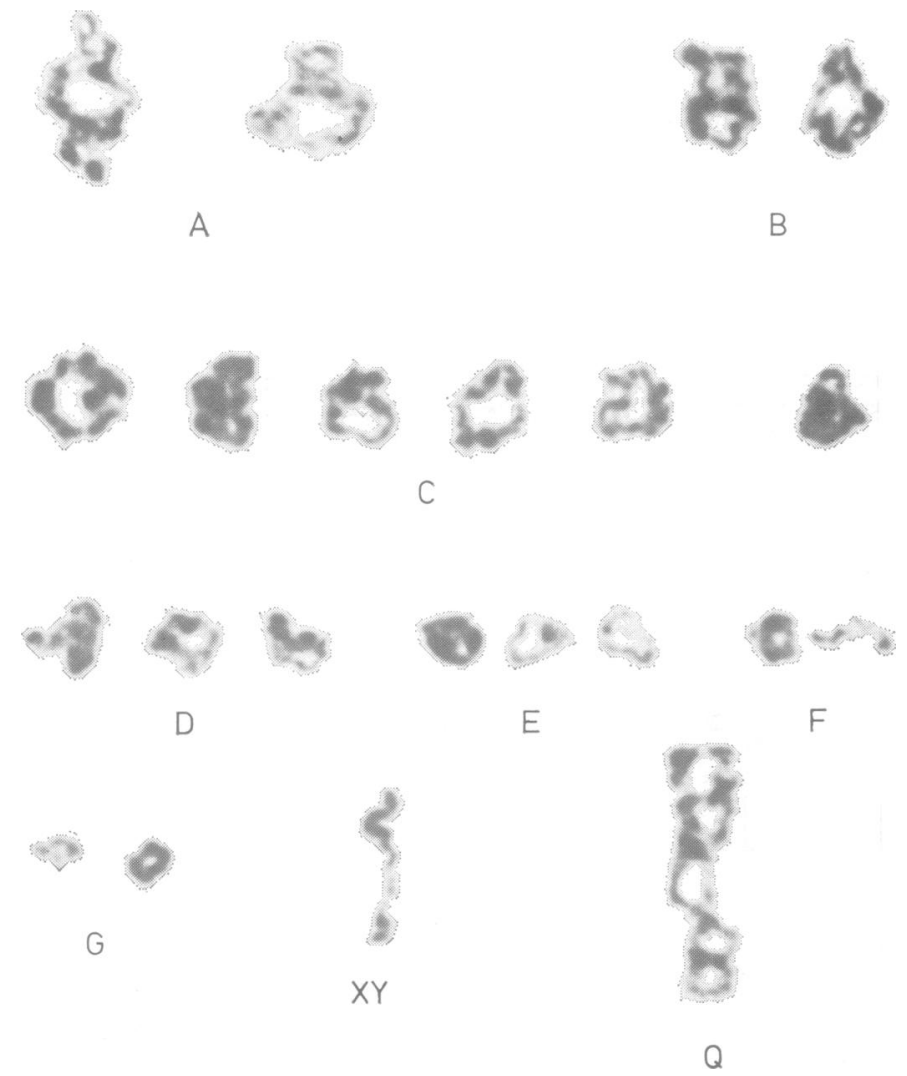

Fig. 3 Case 2. Meiotic karyotype. 
This type of translocation, causing total sterility in mice and men, is also characterised by the presence of a very small marker chromosome in the blood. This is the small $\left(\mathrm{t}^{2}\right)$ product of the translocation which may be passed on to the $F_{1}$ progeny by $3: 1$ disjunction at anaphase $I$ in female heterozygotes, leading to the production of tertiary trisomic offspring.

The second case had a history of subfertility and different findings in meiotic studies. He had ring configurations at diakinesis and no apparent spermatogenic failure, in spite of the low mean chiasma count with a normal distribution of cells through spermatogenesis. It is concluded that alternate segregation led to the production of the normal son, and adjacent I or II to the two malformed children. However, karyotypes were not done for these two children to elucidate the exact mechanism of production.

Acknowledgements are due to the following members of the Fundación Jiménez Díaz: Dr Mendoza of the Infertility Clinic, Dr Vela Navarrete of the Urology Service, and Dr Barat of the Pathology Department. We are also indebted to Mrs M. C. Gacituaga for her technical assistance, and to $\mathrm{Dr}$ A. C. Chandley for her most valuable observations and guidance in the revision of this paper.

\section{References}

Arakaki, D. T., and Sparkes, R. S. (1963). Microtechnique for culturing leucocytes from whole blood. Cytogenetics, 2 , $57-60$.

Cacheiro, N. L. A., Russell, L. B., and Swartout, M. S. (1974). Translocations, the predominant cause of total sterility in sons of mice treated with mutagens. Genetics, 76, 73-91.

Caspersson, T., Zech, L., Johansson, C., and Modest, E. J. (1970). Identification of human chromosomes by DNAbinding fluorescent agents. Chromosoma, 30, 215-217.

Chandley, A. C., Christie, S., Fletcher, J., Frackiewicz, A., and Jacobs, P. A. (1972). Translocation heterozygosity and associated subfertility in man. Cytogenetics, 11, 516-563.

Chandley, A. C., and Fletcher, J. (1973). Centromere staining at meiosis in man. Humangenetik, 18, 247-252.

Chandley, A. C., Seuanez, H., and Fletcher, J. (1976). Meiotic behaviour of five human reciprocal translocations. Cytogenetics and Cell Genetics, 17, 98-111.

Evans, E. P., Breckon, G., and Ford, C. E. (1964). An airdrying method for meiotic preparations from mammalian testes. Cytogenetics, 3, 289-294.

Lyon, M. F., and Meredith, R. (1966). Autosomal translocation causing male sterility and viable aneuploidy in the mouse. Cytogenetics, 5, 335-354.

Paris Conference (1971). Standardization in human cytogenetics. Birth Defects: Original Article Series, 8, No. 7, 1972. The National Foundation-March of Dimes, New York.

Seabright, M. (1971). A rapid banding technique for human chromosomes. Lancet, 2, 971-972.

Requests for reprints to Dr C. San Román, Servicio de Genética Médica, Centro Especial Ramón y Cajal, Carretera de Colmenar, Madrid-34, Spain. 